\title{
Research on Real Estate Enterprise Capital structure and business performance in China
}

\author{
Xiaoguang $\mathrm{Li}^{1}$ and Zhanjun $\mathrm{Gao}^{2}$ \\ ${ }^{1}$ Department of Accounting, HebeiFinanceUniversity, Baoding, China \\ ${ }^{2}$ Department of Foreign Language Teaching and Research, HebeiUniversity, Baoding, China
}

\begin{abstract}
The degree of national macro-control on the real estate market has become stricter, so the financing of the real estate enterprises is becoming more and more prominent. To be not eliminated by the market under the big background, the development of the real estate enterprise must change in vulgar mode, improve the efficiency of the use of funds, optimize capital structure, and choose appropriate financing way, so as to improve the business performance of enterprises.
\end{abstract}

Keywords: Financing Structure; Capital Structure; Real Estate Enterprise;

\section{Introduction}

According to the data from "China statistical yearbook 2010" and is calculated at current prices, the added value of real estate industry in our country in 1978 only $2.19 \%$ of GDP, by 1998 the proportion of more than 4\% (4.07\%) for the first time, after rising to $5.2 \%$ in 2007 , but the economic crisis, fell to $4.69 \%$ in 2008 , in 2009 to $5.48 \%$ of record levels.The rapid development of the real estate industry in our country at the same time, the real estate price has become the corporate theory, as well as the focus of public attention.

After the housing reform, China's house prices, presents the fast growth, the development of the real estate enterprises also ushered in the spring, becomes the one of the most profitable industry in China.But with the rapid growth of housing prices, more and more people cannot buy commercial housing.To social stability and economic sustainable development, the Chinese government issued a series of measures to curb rising house prices, on the demand side, through the detailed measures to reduce speculation in commodity house.On the supply side, funded by the government to build affordable housing, gradually increase the land supply, increase the supply of commodity house.Strong measures of the government, the momentum of rapidly rising prices got preliminary control.

China's real estate industry started relatively late.In the past, the mode of operation is given priority to with the development of the vulgar, but higher profits in the industry. The particularity of real estate products decided the particularity of real estate enterprises financing.Real estate industry is a typical capital-intensive industry, real estate projects of capital utilization and circulation are an essential aspect of real estate development enterprises.Real estate development economic activity requires a lot of money, so the financing for real estate enterprises is particularly important.The current financial environment in our country, the real estate industry financing channel single, lag of financial innovation, investment and financing to real estate enterprises multifaceted financing needs are going unmet. In recent years after the introduction of a large number of high-quality enterprise and capital competition, corporate profits are gradually returning to normal profits, the development of the real estate enterprises in vulgar disadvantages highlighted increasingly.

How to optimize the real estate enterprise's capital structure? How to reduce the average cost of capital? How to improve the efficiency of the use of money?These are all so many real estate enterprises are facing and need to solve a problem.The discussion of this paper starts from them. 


\section{The Basic Theoretical Framework}

Capital is a required element of the enterprise investment, so enterprise financing structure and capital efficiency problem is gaining widespread attention. Improved enterprise management efficiency is to keep the sustainable economic development important force, enhancing national competitiveness. However the improvement of enterprise operating performance requires a lot of money. Differences in financing will in terms of cost, risk, efficiency influence enterprise operating efficiency. And, the existing research focuses on the financing structure, and ignores the influence of capital structure on the enterprise management efficiency. So this paper focuses on the relationship between the capital structures of real estate enterprise management efficiency were studied.

\subsection{Literature review}

Research on capital structure theory system began in 1952 . The American scholar David Durand submits academic papers in the academic convention. He analyzed the early traditional capital structure theory, from three theoretical frameworks comprehensively (NI, NOI theory and traditional theory).

Through researched, this article found that the traditional capital structure theory is based mainly on experience judgments, and it is lack of strict mathematical deduction, and theory's' assumes are difficult to set up, so it is difficult to get the academic consensus.Thus the old theory gradually replaced by the modern capital structure theory.

Modigliani and Miller (1958) put forward the famous MM theory, the first time. On this basis, the relevant theories of modern enterprise capital structure forms gradually.This article selects the improved MM model.

\subsection{The Improved MM model}

MM model without tax was developed by Modigliani \& Miller does not contain the financing model of income tax, it has two big theorems.
- Complete capital market hypothesis.There is no information asymmetry.

$$
C_{u}=C_{l}
$$

$C_{u}$ is no leverage enterprise market value, $C_{l}$ is to have leveraged corporate market value.

- $\quad$ Expected return is equal to the same level of risk of pure equity capitalization rate of flow, and the corresponding risk premium.

$$
i=l_{j}+\left(l_{j}-d\right) Q / F
$$

By the theorem above we can reach the enterprise value, the cost of capital and the relationship between the debt ratios.As shown in figure 1, figure 2 .

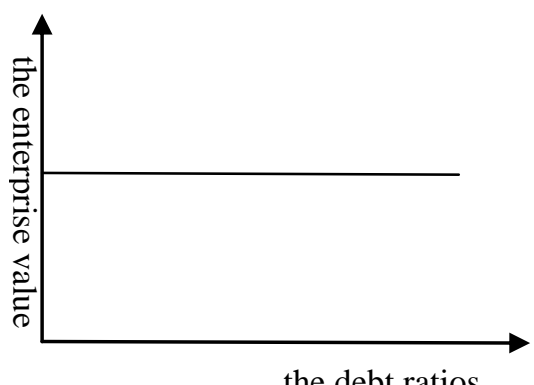

Fig. 1:The enterprise value

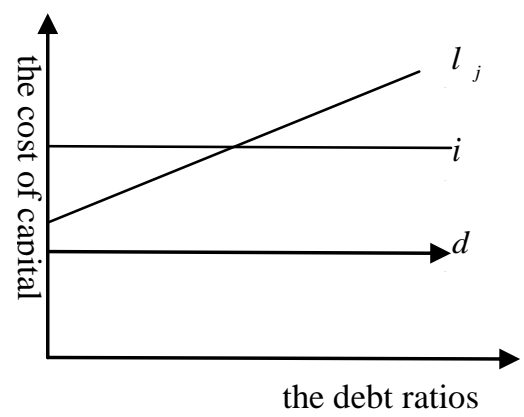

Fig. 2:The weighted cost of capital

Modigliani and Miller (1963) model framework, introduced the enterprise income tax, tax to the MM model correction, put forward two new proposition. 
- Liabilities increase the value of the tax effect to the enterprise, is expressed by formula.

$$
\begin{aligned}
C_{u} & =\frac{E B I T(1-T)}{J_{C R}} \\
C_{l} & =C_{u}+D T
\end{aligned}
$$

In order to better analyze the impact of capital structure on corporate performance, the measurement result is more stability. This article uses panel data combined with improved MM model, through the new method to examine different real estate capital structure impact on corporate performance of listed companies.In the econometric model, besides considering factors of capital structure, and analysis the influence of different equity structure on corporate performance.Econometric model is as follows:

$$
I M P O E_{i o}=a+d_{2} a E_{i o}+b_{n} I M Y_{n, i o}+q_{i o}
$$

POF for real estate listed company's profitability, $\alpha E$ for capital structure, $Y$ as control variables, control variables as population and income factor, $a$ as constant, $q$ for the estimated parameters, E as residual error, I on behalf of the section number, $\mathrm{O}$ represents the time, $\mathrm{m}$ represents the number of control variables, LM said to take $\log$ data.

\section{The empirical analysis}

Entering the 21st century, China's real estate market is developing very rapidly, profit level is high. Does this mean that China's capital structure is more reasonable?

Because of the complexity of the reality and directly applying these theories to the results of the analysis will lead to the certain error. Therefore, this article people theory based on the research thought of before, can be more realistic conclusion by empirical analysis.

\subsection{The Actual Case}

Due to China's micro level statistics is not perfect, so don't have access to all the real estate enterprise's capital structure data and the corresponding business performance. In this paper, using the real estate listed companies as samples for empirical analysis.Databases come from database of GuotaiJunanSecurities.

In order to reduce the volatility of the variable degrees and at the same time solves the problem of dimension. And then to be explained variables and control variables take logarithm, thus reflect the change of data between the rates of change.For the convenience of analysis, the data corresponding to expand ten thousand times, will not affect the results of the analysis.

Table1:

\begin{tabular}{|l|l|l|l|}
\hline & $\mathrm{a}$ & $\mathrm{b}$ & $\mathrm{c}$ \\
\hline VAR & $\mathrm{InPu}$ & $\mathrm{IuPu}$ & $\mathrm{InPu}$ \\
\hline In & $0.765 * * *$ & $0.784 * * *$ & $-12.44 * *$ \\
\hline Cons & 0.289 & -0.0701 & $129.6 *$ \\
\hline Num & 25 & 25 & 22 \\
\hline
\end{tabular}

Annotations: $* * * \mathrm{q}<0.001, * * \mathrm{q}<0.05,{ }^{*} \mathrm{q}<0.1$

The analysis is showed in the table 1.According to the empirical analysis of the impact of return on capital to capital structure, all samples for 25 companies, a total of 248 data.Overall, the capital structure has a significant effect on return on capital, influence coefficient is 0.717 , suggests that every $1 \%$ increase in capital structure, capital yield will increase by $0.717 \%$.However, can be seen from the diagram, the capital structure of the influence of the return on capital to rise, after a downward trend.

Because of leverage, capital structure have a direct role in promoting the return on capital. Return on assets is more dependent on the real profitability of enterprises, rather than financial leverage. Therefore, in addition to the analysis of the effect of capital structure on the return on capital, also need to analyze the capital structure of the influence of the return on assets.

From the correlation diagram of assets structure and capital returns it can be seen that the capital structure of the influence of the return on assets exist three stages, the influence of capital structure is small, when increasing capital structure can improve the return on assets. When the capital structure was in the medium level, capital structure has no effect on return on assets. When the capital structure 
was at a higher level, capital structure is negatively related with the return on assets.

\section{Conclusion}

In this paper, we finish the empirical analysis of the Chinese real estate enterprise capital structure and how to impact on enterprise performance.In the use of listed real estate companies and various provinces and cities after the real estate enterprises to carry out empirical analysis, the results: the capital structure of real estate enterprises has more significant influence on the performance.

By analyzing the data, we can qualitatively the following conclusion: China's real estate enterprise existence of the optimal capital structure, different regions and different development types of real estate enterprise facing the differences between the optimal capital structures. However, from the current management benefit ratio, China's current capital structure is not reasonable, can roughly to see through improving the structure of the assets and liabilities and equity structure two aspects to optimize capital structure, improve the enterprise economic performance.

\section{References}

[1] Supa Tongkong, Key factors influencing capital structure decision and its speed of adjustment of Thai listed real estate companies, pp., Procedia-Social and Behavioral Sciences. 716 - 720, 2012.

[2] Toshiyuki Sueyosh, et.al,Corporate governance and firm performance: Evidence from Japanese manufacturing industries after the lost decade, pp,European Journal of Operational Research. 724-736, 2010.

[3] X.H. Chen,et.al, Credit risk measurement and early warning of SMEs: Anempirical study of listed SMEs in China ,pp, Decision Support Systems. 301-310,2010.

[4] Muler Onofrei, Ion AngheKRisks and Rewards of Leverage in Romanian RealEstate Investment[J],Procedia Economics and Finance. 481 $-488,2012$.

[5] M.H. Chena,et.al. The impact of insider managerial ownership on corporateperformance of Taiwanese tourist hotels, pp. International Journal of HospitalityManagement 2012 (31) :338-349.

[6] Y.S. Kang,B.Y. Kim,Ownership structure and firm performance: Evidence fromthe Chinese corporate reform, pp. China Economic Review. 471-481, 2012.

[7] Augusto de la Torre, et.al,Bank involvement with SMEs: Beyond relationshiplending, pp. Journal of Banking \& Finance. 2280-2293, 2010. 